371.3::821.16

https://doi.org/10.18485/mks_srpska_slavistika.2018.2.ch4

Љиљана Д. БАЈИЋ ${ }^{*}$

Универзитет у Београду

Филолошки факултет

Катедра за српску књижевност са

јужнословенским књижевностима

\title{
ТЕОРИЈСКО-МЕТОДОЛОШКИ ПРОБЛЕМИ ИЗУЧАВАњА И НАСТАВЕ СЛОВЕНСКИХ КЮИЖЕВНОСТИ У ИНТЕРКУЛТУРАЛНОМ КОНТЕКСТУ
}

\begin{abstract}
У раду се испитују теоријски и методолошки аспекти наставе словенских књижевности и култура у компаративној, интерлитерарној и интеркултуралној перспективи. Образлаже се да је појачано занимање књижевних студија за културу, које је обележило деведесете године 20. века, учинило да се у наше време актуализује питање методичке теорије и праксе упоредног проучавања словенских књижевности у мултикултуралном контексту. Рад се посебно бави теоријом и наставом култура као методолошким проблемом. У том смислу, испитују се адекватне методолошке и методичке компетенције за примање и деловање књижевног текста у културном контексту, за интердисциплинарне и интермедијалне везе словенских књижевности са другим хуманистичким наукама и уметностима и за комуникацију са другим културама.

Кључне речи: словенске књижевности, поетика културе, интертекстуална компаратистика, упоредна методика, компаративна теорија.
\end{abstract}

Занимање књижевних студија за појаве у култури доживело је велики процват у доба мултикултурализма. Нове критичке теорије омогућиле су да се књижевност као посебан вид културне праксе испитује у мрежи других пракси у модерном свету испреплетаних заједница и културних идентитета (Culler 2009: 56). Прилазећи предметима културе као текстовима које треба прочитати, ова струја у хуманистици била је подстицајна за тумачење књижевности као интеркултуралне појаве. Означивши правце упоредног истраживања аутора и веза књижевности са другим текстовима културе, она је истакла гледишта на компаратистичке сличности у национално и етнички обележеној литератури и култури, али и значај културног алтеритета, показујући да препознавање књижевних и културних разлика служи узајамном познавању и богаћењу књижевности и културе.

*ica.bajic@gmail.com 
У културној историји позната је појава удруживања појединих књижевности у интерлитерарне заједнице, успостављене између етнички блиских и сродних народа. Постојање таквих заједница повезано је са степеном интеграције књижевних појава и националних књижевности у заједницу која не укида посебности појединачних књижевности. У пракси филолошке науке и високошколске наставе књижевности у свету и код нас овакве заједнице су предмет упоредног истраживања, које пружа увид у развојне процесе и типолошке аналогије унутар заједница, у праћење и испитивање контактних веза, подстицаја и утицаја између националних књижевности, што настаје услед покретљивости, променљивости и размене књижевних елемената у њима. Идеја о упоредној словенској књижевности има своју основу у сродности језика који, како је писао Јакобсон (1987: 23), обједињује Словене, у припадности словенских језика истој језичкој групи, у заједничком митолошком и фолклорном наслеђу Словена. Дуга традиција културних односа била је подстицај за прве кораке културних посленика (Шафарик, Колар и други), а касније и за упоредно проучавање појединих словенских књижевности на универзитетима (Москва, Петровград, Варшава, Праг, Београд и други) од 19. века до нашег времена, у коме су геополитичке и друштвене промене актуализовале дијалог регионалних култура и проучавање култура словенских народа.

Када је у питању настава књижевности у нашој школи, може се говорити о извесном одабраном корпусу програмских дела из других словенских књижевности изван матичне која се обрађују као наставни садржаји. Не улазећи у курикуларне основе и разлоге ове појаве, несумњиво је да би и на школском узрасту настава у којој би се уз проучавање српске остварио одговарајући увид и у друге књижевности, а посебно у сродне словенске књижевности, обезбедила већи прираштај знања и оснажила читалачке компетенције ученика. Ширење поља интересовања од српске ка словенским књижевностима (на пример, кроз изборни предмет или додатни садржај рада у школама филолошког усмерења) било би од значаја за упоредно истраживање појава у књижевности и култури које се одвијају у сфери интертекстуалности и културног дијалога.

Стицање научних знања и стручних компетенција за теорију и праксу савремене наставе књижевности у школи отворене према међупредметним везама у хуманистичком образовању истиче потребу оспособљавања наставника за компаратистичка истраживања књижевности и за методику њеног упоредног изучавања. У данашњим условима савремена методика налази се пред задатком и изазовом да понуди одговарајуће методолошке и методичке компетенције за проучавање књижевног текста, за његово примање и деловање у контакту са другим предметима и областима културе, за истраживање интердисциплинарних веза књижевности са другим уметностима и хуманистичким наукама. Развијајући се у складу са таквим потребама, упоредна методика, као нова област методике наставе књижевности, омогућила би подизање нивоа књижевне културе и стварала предуслове за комуникацију са другим књижевностима и културама. Своју стручну методологију она треба да развија на основама књижевнонаучне методологије, користећи плуралност метода и методолошке процедуре усклађене са језичком и естетском природом књижевног дела, са фикционалним односом књижевности према спољашњем свету и са њеном интертекстуалношћу и самосвојношћу. Проширујући истраживачко поље 
са књижевности ка компаративној књижевности и култури, она треба да има у виду и нове правце изучавања књижевности у доба мултикултурализма, као и да развије методичку теорију и праксу упоредног проучавања књижевности у чијем средишту је читање, доживљавање, упоређивање и тумачење књижевног текста путем уочавања и образлагања његових сличности и разлика са другим текстовима, као и односа са читаоцем и читалачких стратегија које примењује. Овај задатак има посебну тежину не само у настави књижевности на школском (средњошколском) нивоу, у којој су узрастом полазника ограничени садржаји рада и њихово знање, већ, како је примећено, и у једном делу изучавања књижевности на Западу повезаним са наставом књижевности у којој се књижевност тумачи првенствено као простор за дијалог између култура и „оснажује космополитски етос”, као и услед чињенице да је појам светске књижевности од одреднице за област истраживања „еволуирао” у одредницу „новог критичког метода” (Juvan 2013: 127).

У условима интеркултурализма, који прихвата и артикулише односе/комуникацију између различитих заједница, дидактичка теорија књижевног образовања мора уважити постојање и испреплетаност различитих културних образаца као сазнајних (васпитних и образовних) вредности, когнитивних компетенција и уобичајених пракси у свету. Дијалог културних садржаја, као тему образовне и васпитне праксе, требало би развијати кроз облике рада који воде према активном односу једне културе са другим културама, ослобађању од недоумица, предрасуда и незнања о њима и њиховом разумевању и прихватању. У том смислу, дијалог култура је битна димензија савремених научних, наставних и образовних процеса. Он се на адекватан начин укључује у садржаје образовања и хуманистичког васпитања, омогућавајући кроз размену културних образаца сазнавање и прихватање посебности култура, као и космополитских вредности које се њима посредују.

Методолошки утемељен и добро организован разговор о књижевним текстовима и анализа њихових различитих функција, посебно лингвостилистичке, естетске, аксиолошке и културолошке, води учеснике дијалога према сазнајној истини за којом заједнички трагају. Овакав дијалог није могућ ако се не одвија у сфери интеркултуралности и интерсубјективности где Ја перципира Другог као неког ко припада и њему, где је Ја присутно тек заједно са Другим. Непознавање културних образаца и разлика у животној пракси може побудити различито реаговање, од неразумевања и неприхватања до прихватања и смеха. Пишући о смеху у студији Проблеми комике и смеха, Владимир Проп комику културних разлика објашњава на следећи начин:

„Ако се сложимо да сваки народ има своје спољашње и унутрашње норме живљења које се конституишу са развојем културе, онда ће нам се све оно што овим нормама не одговара чинити смешним. Овде се крије разлог зашто нам тако често странци изгледају смешни. Они су заправо смешни само уколико се нечим издвајају, својим необичностима разликују од оних код којих су допутовали" (Проп 1984: 56).

За ефекат и деловање смешног који настају из цивилизацијских разлика и укрштања супротних животних навика илустративан је одломак из путописа Писма из Италије Љубомира Ненадовића. Одломак побуђује смех и пријатне доживљаје, па се тим путем издваја као занимљиво место које привлачи пажњу и памти се. 
У хумористички интонираној ситуацији у Нероновим бањама, италијанском летовалишту у коме су се нашли Ђука и Вукало, пратиоци црногорског поглавара и владике Његоша, смех извире из свакодневних прилика у којима се придошлице не сналазе. Како припадају другој култури, Ђука и Вукало не познају начин живота и навике Италијана, па им бања не личи на лековито купалиште у коме се може уживати, већ на неку ђавољу рупу. Зато је њихово понашање, којим се издвајају од околине, необично и смешно. Што су разлике оштрије, то је њихов комични потенцијал већи. Овде је остварен Вукаловим изгледом (из рупе са топлом водом излази сав знојав и прљав) и Ђукиним необичним понашањем и речима: „Ђе си, јадан Вукало? Ја мнија (мишљах) е погибе у ту ђавољу бању!”. Ђукине речи су у функцији карактеризације овога лика, али се могу коментарисати и шире, као пример комике подстицане типовима културних разлика. Јер по распрострањеном схватању народа коме Ненадовићеви јунаци припадају, рупи (јами, провалији) придаје се смисао доњег света или приступа у њега (Чајкановић 1973; Толстој, Раденковић 2001). Довољно је сетити се да је јама у коју је упало Пепељугино вретено у истоименој српској народној бајци један такав улазак. Исти образац архаичног мишљења у Ђукином доживљају у овакво кобно место уводи и Вукала јер је за Ђуку бања материјализована представа провалије којом се улази у други, доњи свет. Тако комични предмет произведен путем додира култура омогућава да се упозна оно што је различито, у датој ситуацији препозна као шаљиво и да се разуме и прихвати уз помоћ добронамерног смеха.

Комуникација са различитим културним просторима има несумњив образовни и васпитни значај. Знања и способности који се на тај начин стичу (интеркултурна компетенција) помажу да се боље функционише у савременом вишекултурном и вишејезичном свету, и да се, усвајајући одговарајућа правила културе и систем признатих/поштованих вредности, припреми за живот у мултикултуралном свету. У нашој образовној и васпитној пракси, као и у пракси у свету, интеркултурна компетенција повезују се са програмом и исходима билингвалног учења. Његова посебност је у томе што се на основи два језика и две културе ствара мотивација и база за даље усвајање других језика и књижевних и културних садржаја. Отварајући се и за полилингвизам, двојезично образовање води ка изградњи позитивних плурилингвалних и културних идентитета, ставова према другима, као и ка формирању хуманих, локалних и глобалних, етничких и културних заједница.

Студије и настава словенских језика, књижевности и културе на универзитетима и у школама у словенском свету разликују се међу собом у мери у којој се разликују предмети и области/појаве којима се оне баве. Међу српским славистима углавном је прихваћено становиште по коме се издвајају три вида изучавања словенских језика и то као матерњих, инословенских и страних. Разложно се истиче потреба за развијањем посебне методике изучавања српског, руског и осталих словенских језика као инословенских, али се ова грана методике није конституисала као кохерентна и посебна у методолошком и теоријском смислу. Па ипак, може се закључити да су одређене методе, као што је метода конфронтационе анализе у настави словенских језика у инословенским срединама и метода компаративног проучавања књижевног текста у инословенском контексту заузеле 
значајно место у нашој лингводидактици, методици наставе књижевности и лингвокултурологији.

Компаративни поступак и могућности његове примене у проучавању књижевних дела у инословенском контексту аутор овога рада обрадио је у ранијим текстовима на примерима књижевних дела српских и руских писаца. Зато ће овде у сажетом виду бити изнето, образложено и илустровано само методичко полазиште поредбеног читања и тумачења књижевних текстова.

У стварању методичких пројеката за рад на делима словенских писаца узима се у обзир чињеница да је њихова рецепција обично посредована преношењем књижевног текста са једног на други језик. Превод има посебан значај у међулитерарним процесима јер књигу чини доступном ширем кругу читалаца. Али са преводом текст се из матичне културе и књижевног система преноси у културу и књижевни систем другог језика, па је тиме условљено не само примање већ и деловање и вредновање текста, за које се може рећи да су „отежани” у мери у којој се оригинал изворника разликује од (варијаната) превода. Зато се у проучавању изворни текстови, када год је то могуће, доводе у непосредан поредбени однос и на тај начин појачава њихово примање и аутентично разумевање и тумачење.

У основи упоредног проучавања налазе се мисаоне радње и логичке методе неопходне за успешну истраживачку делатност и поуздано закључивање, на првом месту, поређење (компарација), као и индукција и дедукција, анализа и синтеза и метода решавања проблема. Поредбена/упоредна метода омогућава паралелан увид у два или више поредбених релата са циљем да се уоче и образложе сличности и разлике књижевних феномена унутар националних књижевности и/или унутар субнационалних књижевних појава. Поредбеним поступком у корелацију се доводе феномени исте или сродне врсте (синхроне и дијахроне везе у националној књижевности, контакти између две или више националних књижевности, однос књижевности са медијима или њено преплитање са другим манифестацијама и областима људског духа), у којима се уважавају њихове посебности, варијантност, варијабилност и различитост.

Методолошки основ упоредног тумачења књижевних дела словенских писаца има своје упориште у тематолошким, поетичким, жанровским, стилским и идејним појавама, односно у књижевноисторијским, књижевнотеоријским и културолошким чињеницама. Корелативно становиште успоставља се према појединачним појавама које улазе у сферу утицаја и прожимања, као и према подручјима којима те појаве припадају. Као пример може се навести компаративни приступ теми бедних људи у делу Ф. М. Достојевског и Борисава Станковића. За руску класичну литературу традиционалан је критички став према социјалним проблемима и разумевање малог човека. Судбина ситног чиновника, невољника, човека кога су несрећне околности довеле у беду или га гурнуле на дно живота, занимала је Пушкина (Станични надзорник), Гогоља (Шињел) и Достојевског (Бедни људи, Понижени и увређени, Злочин и казна). У новој српској књижевности живот сиромашних, просјака и болесних људи посебно је обрадио Борисав Станковић у наративном циклусу под насловом Божји људи. Станковићеви божјаци припадају уметничком типу чудака и просјака. Они се као културолошки феномен повезују са контекстом социјалне критике и у типолошкој су сродности са јуродивима руске књижевне традиције, по- 
себно Достојевског. И сам Станковић своју заокупљеност светом божјака објаснио је речима према којима се мотив божјака може довести у ширу везу са поменутом традицијом. ${ }^{1}$ Компаративно проучавање Бедних људи Достојевског и Божјих људи Борисава Станковића показало је да се у Станковићевом односу према Достојевском може говорити само о усвајању његове основне концепције о јадним људима, док се изван тог контекста Божји људи повезују са великим утицајем фолклора на Станковића, у коме божјак, односно просјак, представља митског претка. Упоредно читање Достојевског и Станковића (Бајић 2017а) утврдило је да сличност између њихових дела потиче од типолошке сличности тематике тих дела (сиромаштво, манијакална тематика, страсти које се граниче са лудилом, болест), на једној страни, и етике добра, хуманистичког става и разумевања за предочени свет, на другој страни.

Поредбена метода често се примењује у настави књижевности. Обично се, на пример, упоређују књижевни текстови једне епохе или стилске формације, дела сличне тематике, мотива и ликова, експресивни делови истог текста, вредносни чиниоци у једном или више дела једног или више писаца, а у поредбени однос могу се довести и уметничке чињенице са чињеницама из објективне стварности (Бајић 1994; Николић 1998). Да би се одговорило изазову компаративног тумачења књижевних текстова, у раду је потребно користити њихово упоредно читање и сазнајне процесе уздићи на раван критичког (проблемског) мишљења. Ако се као поредбени релати узму Нушићеве и Гогољеве комедије Сумьиво лице и Ревизор, онда се у проучавању могу издвојити и решавати следећи литерарни проблеми (Бајић 2017б: 234-236):

Реалност и привид у комедијама

Креатурално и гротескно изобличавање корупције, мита и устројства друштва превођењем типичног у осредње и ништавно

Смехотворни поступци у Гогољевој и Нушићевој комедиографији

Врсте смеха у појавама ружног, настраног и ниског у комедијама

Гогољ и српска књижевност реализма

Гогољ и хумористичка и сатирична књижевност код Срба

Жанровски контекст Ревизора и Сумњивог лицуа (динамика заплета, јавно и приватно у комичном конфликту ова два комада, ликови као поредбени релати, присуство/одсуство визуелних и аудитивних сценских елемената и њихова драматуршка функција у комедијама)

Ревизор и Сумьиво лице на позоришној сцени (увид у позоришну историју комедија, репертоар и време њиховог сценског извођења, пријем комедија код публике и позоришне критике)

Позиција читаоца и позиција гледаоца комедија Ревизор и Сумњиво лице, која омогућава виђење комичног предмета из двоструког угла

Када се у корелативни методички наставни систем укључује компаративно изучавање дела српске и руске књижевности која припадају истим књижевним

\footnotetext{
${ }^{1}$ У писму Милану Савићу, уреднику „Летописа Матице српске”, Станковић наводи:

„Имам једну збирку, тзв. Божји људи. У њој сам покупио и изнео један нарочити свет, поколење које је било у Врању пре ослобођења. То су били просјаци, слепи, гатари, видари, биљари и други. Сви су они живели од милостиње. Јер се веровало: да што се њима да, да они поједу у покој душа умрлих, као да се је самим мртвима дало и да су они то мртви, појели. Међ њима је било који су сматрани за свеце, божје људе. И кад би ти умрли, били су од највиђенијих (старих жена) купани, сарањивани...

Уопште налик на руске јуродиве...

Само у већој, јачој размери" (Станковић 1979: 340-341).
} 
жанровима, тада се у поређењу користе гледишта на поетику, теорију, историју и праксу тих жанрова. На пример, ако је у питању драмско дело Гогоља и Нушића, комедије Ревизор и Сумьиво лицее, онда се у синхроној поставци анализирају њихови књижевни и сценски елементи. Начело двоструке корелације овде је повезано са схватањем драмског текста као посебне форме књижевног дискурса, специфичне по томе што садржи „текстуалну матрицу представљачког”, односно, „иманентну театралност" (Miočinović 1981: 40). Из односа драме и позоришта развила се методичка теорија о литерарном и театролошком приступу драмском делу, о синхроности бинарних гледишта на драму као књижевну и сценску уметност. Та теорија пружа основу за компаративно литерарно и сценско читање како комедиографских дела Ревизор и Сумњиво лице (Бајић 2017б: 232-233), тако и других драмских дела и жанрова у руској и српској књижевности.

Компаративно проучавање обухвата и област књижевних контаката (као у примеру Пушкина и Гогоља, или у примерима контаката Горког са Чеховом и Толстојем), утицаја (познати су примери утицаја Пушкина на Његоша и Гогоља на Нушића), стваралачког надахнућа, подражавања. Истраживања утицаја и сведочанства о њима пружају слику о књижевним кретањима, континуитету и променама у књижевности. Чак и летимичан увид у Гогољево присуство у књижевном животу код Срба може осветлити временски знатан период наше културне историје 19. века, када је, како сматра Јован Скерлић, пишчев утицај на српску књижевност био нарочито велики. У литератури је познато да је Гогољ био подстицај за комедиографска остварења Бранислава Нушића писана осамдесетих година тога века, на првом месту за Сумьиво лице. Одјек Гогољевог дела илуструје, на пример, податак да су Милован Глишић и Лаза Лазаревић своју књижевну делатност започели преводећи 1870. године, још као ђаци Велике школе, по једну Гогољеву приповетку (Бавоља посла, Иван Фјодорович Шпоюка и његова тетка). Гогољев утицај опажа се и у делима других писаца тога времена, Ј. Веселиновића, С. Ранковића, И. Вукићевића, Ј. Игњатовића, С. Сремца, Р. Домановића, а у књижевности и сценској уметности може се пратити до нашег времена. О пријему Гогољевог дела у нашој културној јавности говори и неколико података о комедији Ревизор на позоришној сцени. Објављена и исте године премијерно изведена у Александријском позоришту у Петровграду 1836. године, ова комедија код нас је први пут приказана на сцени Народног позоришта у Београду 1. фебруара 1870. године, три месеца после оснивања ове позоришне куће. У режији Алексе Бачванског лик градоначелника тумачио је Адам Мандровић, а Хљестакова Милош Цветић, на премијери, и Тоша Јовановић, на првој репризи. У време када је позоришни живот у Србији био на почетку, а млада, још малобројна публика неспремна за Гогољев сувише тежак комад, Ревизор је поделио позоришну публику и критику, која се није сложила у његовој оцени. Како комад тада неко време није доносио потребне материјалне приходе, он је као скуп морао уступити место лакшим и јефтинијим комадима. Али доживљавајући током дугог живота низ обнова, Ревизор је на позоришној сцени код Срба остао позоришни догађај који траје до данас. О утицају и значају ове комедије сведочи и Бранислав Нушић у предговору свога Сумњивог лища, комада на чијем је оригиналном рукопису написано да је то „гогољијада у два чина” (Нушић 1966: 8). Према Нушићевим речима Гогољ је био најпопуларнији писац у чијој је комедио- 
графији слика руске бирократије била истоветна са тадашњим српским друштвом (Нушић 1966: 7). Занимљива је чињеница да је српски писац као драматург и вршилац дужности управника Народног позоришта Ревизора ставио на репертоар када се обележавала педесетогодишњица Гогољеве смрти (1902). По доласку у Сомбор (1904), Нушић је међу првим премијерама опет приказао Ревизора. Томе је помогла Јулијана Костић, супруга песника Лазе Костића. Она је дала „о своме трошку зготовити све за представу”, а то је коштало преко 800 круна. Представа је трајала и наредне сезоне, све до 1907. године, а њена обнова те године поново је везана за делатност Бранислава Нушића као драматурга Народног позоришта (Лешић 1981: 19-20). У каснијим годинама $(1921,1937)$ представа Ревизора постигла је велики успех у режији бивших чланова Московског художественог академског театра Јурија Ракитина, Вере Греч и Поликарпа Павлова (Косановић 2011: 144-145). Након Другог светског рата Гогољ је извођен у свим нашим већим градовима и културним центрима. Иако је у актуелном времену Гогољево присуство у позоришном животу смањено, могло би се рећи да је код нас сваки нови покушај да се оно растумачи и актуализује био важан културни и уметнички догађај.

Поредбено истраживање контаката, утицаја, прожимања и сличности између књижевних појава обавља се са циљем да се оне приближе једна другој или другим видовима уметности, културе и знања, те да се чињенице и текстови раздвојени језиком повежу и кроз интертекстуални однос боље схвате њихови књижевни, жанровски, традицијски, религијски, етички и културолошки елементи. Адекватан избор књижевних садржаја, било да су они преведени, или да су на језику оригинала, у одломцима, или у посебним хрестоматијама, омогућава упознавање са другим словенским културама, са сличностима и културним особеностима заједница чији се језик учи. Пружајући знање о другом, о другачијем или непознатом, књижевни текст помаже разумевању и интегрисању стеченог знања и искуства у сопствени културни модел понашања и веровања читаоца. Са књижевним текстом на вишим нивоима учења словенских језика (Ц1, Ц2), функционално се проширују лингвистичка, књижевна и културолошка знања, а у корелацијско-интеграцијском систему филолошких студија језика, књижевности и културе ове три програмске области повезују се у интегрисана подручја научног и наставног рада.

На нивоу наставе у школи контакти између различитих националних књижевности чине посебан тип корелације који има свој дидактички еквивалент у теорији међупредметних веза. Уместо традиционално затворених наставних предмета, теорија међупредметних веза истиче корелацију програмских садржаја у јединствене програмске целине (Росандић 2005: 252). У области друштвеног и језичко-хуманистичког образовања и васпитања програмске целине остварују се путем тематске корелације наставног градива, тако да теме које се проучавају у ширем контексту / подручју рада или наставном предмету добијају у опсегу и интензитету обраде. У корелацијско-интеграцијском систему настава књижевности се на начелима компаративне естетике доводи у везу са другим уметностима (филмском, ликовном, музичком, сценским уметностима). Овде се тематски однос између самих књижевних дела и књижевних дела и других уметности прати на рецепцијском и синхронијском плану, а обухвата и проучавање историјског и стилског контекста, као и интермедијална истраживања веза књижевности и позоришта и књижевности и фил- 
ма. Према тумачењу методичара књижевног образовања и васпитања повезивање књижевности са осталим подручјима уметничког стварања представља тековину новије методике. Корелација и интеграција уметничких садржаја, који имају своје историјско и теоријско утемељење и разлоге, омогућава остваривање приоритетних циљева естетског образовања и васпитања. Сврховитост интегрисане наставе у школи налази се у развијању љубави према књижевности и уметности, изграђивању уметничког укуса и критичког става у просуђивању уметничких дела и вредности, формирању хуманистичког погледа на свет, у коме се афирмишу стваралачке и културне потребе ученика као читалаца и посетилаца концерата, изложби, биоскопа и позоришта.

Током историје, у којој је долазило до подударања и разилажења различитих уметности, међу њима су се успостављали утицаји који су их могли надахнути и повезати. Тако су нека песничка дела писана са намером да им се дода музика (оперски либрето), сликарска и музичка дела била су инспирација за дела књижевних уметника, а било је утицаја и у повратном смеру, као у случају Гогоља и Шостаковича, који је по пишчевој приповеци Нос написао истоимену оперу 1928. године. У њој су, под утицајем Мајерхолда и његове режије Ревизора, јунак и сиже дати у стилу трагичне „буфонаде” (Стахорски 2013: 378). Илустративан је и пример драме Борисава Станковића према којој је Петар Коњовић компоновао оперу Коштана. Чар и сценске могућности које Станковићев текст пружа композитор је видео у музичким елементима комада, у његовом унутрашњем прожимању са народним лиризмом. У ширем контексту Коштана се може довести и у везу са Бизеовом опером Кармен, као и са позоришним комадима са песмом и играњем који су почетком 20. века били популарни на позорници код Срба. Преко драме и опере читаоци и гледаоци успостављају однос и са данас актуелним позоришним и музичким жанром, мјузиклом. За тему је карактеристичан и пример који пружа стилска формација авангарде у својим поступцима колажа и монтаже, слика са текстом и конструката више уметности, а интермедијално преплитање наћи ће се и у постмодернизму (перформанси, инсталације и слично).

Стваралачка пракса показује да су се у појединим раздобљима различита уметничка подручја могла додиривати и међусобно преплитати: поезија са музиком у романтизму и симболизму, поезија са бојом и сликом код парнасоваца или код имажиниста, а изражајна средства једне уметности могла су бити препозната у другој, као у примеру „музикализације” неких романа тока свести. Ако се у настави корелација књижевности са другим уметностима користи током обраде књижевних праваца и епоха, онда се аналогије и разграничења између проучаваних појава изводе на основу поетике и естетике раздобља, жанрова и поступака, као и на основу културноисторијског контекста. Као пример може послужити корелација наставе књижевности и ликовне уметности у обради епохе реализма, у којој се књижевни текст, у настојању да миметички одрази стварност, користи жанром слике и поступцима визуелног изражавања. Потврде се могу наћи и у мноштву других примера: песмама Војислава Илића или песмама Сергеја Јесењина, чији се мотиви и поетска атмосфера могу довести у поредбени однос са сликарским делима Шумановића и Шишкина, у одговарајућим садржајима Станковићеве Нечисте крви и мотивима у слици Кићење невесте Паје Јовановића, у књижевном делу Лава Толстоја и виђењу 
писца у портрету Иље Рјепина и слично. Корелација књижевности са другим уметностима треба да послужи развијању књижевног знања и естетских могућности ученика и да економише наставним поступцима и временом рада.

Приликом упоредног читања и тумачења књижевних дела српских и словенских писаца разложни приоритет добијају дела школских класика, писаца који чине школски канон. ${ }^{2}$ Такви писци у програму, као што су Станковић и Чехов у овом примеру, представљају стални подстицај за наставу књижевности у школи. Са Чеховом и Станковићем отвара се посебно поље рада, богат спектар интермедијалних веза њихових књижевних дела и других медија, посебно позоришта и филма.

Чеховљево дело има јак утицај на европски и светски филм и позориште. Налазећи драматичност у свакодневици, у испразности и промашености живота, у отупелости осећања, досади и чамотињи, Чехов је створио дела која су означила раскид са традиционалним облицима драме. Нову естетику и драматургију има и драма Ујка Ваға, која је у програму наставног предмета Српски језик и књижевност. Зато се у настави овом делу прилази као особеном и препознатљивом за чеховљевско позориште. Дело нема класичну драмску радњу и оштро издвојене драматичне догађаје већ је уроњено у свакодневицу збивања у којој се сударају узвишено и тривијално, озбиљно и банално. У складу са тим чињеницама, литерарно и театролошко читање/тумачење драме подешава се према њеним лирским, поетским и психолошким особитостима, према посебном ритму и темпу у дијалозима, али и у паузама и усмерава тумача на анализу стања јунака и посебан сценски језик комада. У обради драме користе се адекватна гледишта за њено локализовање и поредбени осврт на књижевно дело и позоришну и филмску адаптацију. Драма се појавила у збирци позоришних комада 1897. године а њено прво извођење било је у Московском художественом театру 1899. године. Једна од насловних улога у драми (Јелена Андрејевна) била је поверена глумици из трупе Станиславског, Олги Книпер, будућој супрузи Чехова. Драма је имала низ позоришних и филмских екранизација у свету, које би, попут филмске верзије Андреја Кончаловског и Лоренса Оливијеа, могле да привуку пажњу ученика и подстакну их на поредбено тумачење литерарног предлошка на филму и позоришној сцени. Код нас је Ујка Вања, међу првим, позоришној публици представљен у тек створеном Југословенском драмском позоришту 1947. године у режији Бојана Ступице. Са преводима на друге језике Чехов је почео да стиче популарност и код англосаксонске публике. Такав пријем Чеховљевог дела, између осталог, може се објаснити чињеницом да се у данашњем свету глобалне културе овај писац схвата као тумач безнађа и апсурда живота, доминантних осећања савременог човека, која су праћена губитком вере у смисао егзистенције.

Пишући о Чехову на позоришној сцени, Милан Дединац и Милутин Бојић довели су драматургију и естетику овога писца у везу са писцем Коштане Борисавом

\footnotetext{
${ }^{2}$ Уобичајено је да у оквиру националне књижевности књижевни канон означава ауторе који су признати као најзначајнији. Сматра се да је процес формирања књижевног канона отворен за „консензус” критичара и научних радника, у том смислу и за преиспитивање унутар културне заједнице, као и да је за пут који једног ствараоца уводи у канон од значаја његово проучавање у оквиру школског програма. Књижевни канон, на једној, и „школски канон”, на другој страни, повезани су тако да књижевни канон, као надређени систем стандардних вредности, утиче на функционални подсистем, који чини садржаје школског програма.
} 
Стаковићем. Иако се не може говорити о Чеховљевом утицају на Станковића (Чеховљева драма код нас је била скоро непозната у време када Станковић пише Kouтану), постоји основ за повезивање драма ових писаца. И Коштана и Ујка Вања на лирски начин говоре о „трагизму промашених живота”. Сличне особине ових дела настале су у оквиру сродне поетичке праксе. Оне се могу објаснити чињеницом да су оба писца радила у истом времену и припадала истом књижевном сензибилитету, ,за који је карактеристично мешање родова и жанрова” (Божовић 1985: 35-36).

Борисав Станковић има прекретнички значај у развоју модерних токова у српској књижевности 19. и почетком 20. века. Међу писцима на раскрсници векова, који су померали границе српске прозе, њених облика и изражајних могућности, Станковић је био један од најзначајнијих. Књижевно дело овога писца је жанровски разноврсно, али због своје синкретичности, преплитања епских, драмских и лирских садржаја, излази изван оквира традиционалних жанрова. Поетска својства најбоље драме Коштана потичу од лирских монолога и народних песама и певања, којима се надокнађује закоченост њених дијалога и сукоба на сцени. Познато је да је подстицај за ову драму писцу дошао од тадашњег драматурга Народног позоришта у Београду, Драгомира Јанковића, који је писцу предложио да на основу мотива у причи Наш Божић напише „нашу Кармен”, као и да је ова драма на сцену пренета и као оперска представа. Прва Коштана била је изведена на сцени Народног позоришта 1900. године. Драму је режирао и Миткин лик тумачио познати комичар Чича Илија Станојевић, музичке аранжмане урадио је Фрањо Покорни, а лик Коштане тумачила је Зорка Тодосић. Занимљиво је да су тада настали први неспоразуми око реализације драме на сцени, коју глумци и режија нису адекватно дочарали публици, тако да Коштана, иако замишљена као комад са певањем који се уклапао у позоришну традицију са наклоношћу публике, није доживела одмах успех код гледалаца и критике. Од тога времена до наши дана она је извођена на свим значајним сценама у земљи. Током свог позоришног живота Коштана је прешла пут од традиционално режираног и играног фолклорног комада са игром и певањем до модерно стилизованог и интерпретираног комада отворене драматургије, што је допуштало да се дело драматуршки преобликује, оживи и усклади са сензибилитетом савремених гледалаца (Бајић 2013: 355).

Увид у позоришне и оперске представе Коштане, који се може остварити у настави, показао би различита сценска тумачења дела. Јер, у Станковићевој драматургији песма и игра нису традиционални, забављачки елементи, живописне илустрације фолклора, већ јединствене форме уметничког изражавања, облик и израз емоција, који приказују тренутке страсти и прате ритам осећања. У тумачењу драме њена оригиналност показује се анализом сижејних елемента текста, посебно структуром драмске радње, редукованом на неколико драмских ситуација са конфликтним тачкама које су нађене у покретима душе, а не у спољашњим токовима драмске радње, и везане за драматично напрегнут сценски простор. Комад који је, уобличавајући патњу Митке и Коштане, радњу схватао као израз емоција, тражи поетско чуло и имагинативну слободу читалаца, извођача и гледалаца (Бајић 2013: 357). Отварајући се према интими и лирици и препуштајући се продуктивној активности читалаца и публике, Коштана до данас чува своје место у књижевној и позоришној култури Срба. 


\section{Литература и извори}

Бајић Љ. Методички приступ збирии приповедне прозе. Београд: Завод за уџбенике и наставна средства, 1994.

Бајић Љ. „Читање драме.” Кюижевност и језик, св. 3-4 (2013): стр. 351-362.

Байич Л. „Этика добра в художественном творчестве Ф. М. Достоевского и Б. Станковича.” Славянский вклад в мировую цивилизаџию. Волгоград: Научное издавательство ВГСПУ «Перемена», 2017а: стр. 280-292.

Байич Л. „Творчество Гоголя в современном преподавании литературы в Сербии.” Гоголь и славянский мир. Москва: Департмент культуры г. Москвы - Дом Гоголя - «Новосибирский издательский дом», 2017б: стр. 231-238.

Божовић 3. Чехов као драмски писаи код Срба. Београд: Филолошки факултет, 1985.

Якобсон Р. Работы по поэтике. Переводы. Москва, 1987.

Косановић Б. Нове компаративне теме. Нови Сад: Филозофски факултет, 2011.

Лешић Ј. Нушићев смијех. Београд: Нолит, 1981.

Николић М. Методика наставе српског језика и књижевности. Београд: Завод за уџбенике и наставна средства, 1998.

Нушић Б. Сумғиво лиие. Хајдуии. Београд: Издавачко предузеће Јеж, 1966.

Проп В. Проблеми комике и смеха. Нови Сад: „Дневник” - Књижевна заједница Новог Сада, 1984.

Станковић Б. Стари дани. Божји људи. Београд: Просвета, 1979.

Стахорски С. В. (ур.). Енциклопедија књижевних јунака. Београд: Плави круг - Невен, 2013.

Толстој С., Раденковић Љ. Словенска митологија: енщиклопедијски речник. Београд: Cepter Book, 2001.

Чајкановић В. Мит и религија код Срба. Београд: Српска књижевна задруга, 1973.

Juvan M. „Posvetskivanje književnosti između dijaloga i hegemonije.” Култура: у потрази за новом парадигмом. Београд: Филолошки факултет, 2017: стр. 121-143.

Kaler Dž. Teorija književnosti (sasvim kratak uvod). Preveo Dragan Ilić. Beograd: Službeni glasnik, 2009.

Miočinović M. Moderna teorija drame. Beograd: Nolit, 1981.

Rosandić D. Metodika književnog odgoja. Zagreb: Školska knjiga, 2005. 
Лиляна Д. Байич

\begin{abstract}
ТЕОРЕТИКО-МЕТОДОЛОГИЧЕСКИЕ ПРОБЛЕМЫ ИЗУЧЕНИЯ И ПРЕПОДАВАНИЯ СЛАВЯНСКИХ ЛИТЕРАТУР В МЕЖКУЛЬТУРОЛОГИЧЕСКОМ КОНТЕКСТЕ
\end{abstract}

\title{
Резюме
}

В работе дается краткий обзор научных трудов по изучению культуры, гуманистического направления, актуализирующих вопрос методической теории и практики сравнительного изучения славянских литератур в межкультурологическом контексте. В текущих условиях перед современной методикой стоит задача развития своей новой области, сравнительной методики, которая призвана обеспечить соответствующие знания для сравнительного литературоведения. Принимая во внимание существование и переплетенность множества культурных моделей и обычной практики, сравнительная методика использует соответствующую методологию в целях изучения взаимоотношений и взаимопроникновения культурных и литературных проявлений, исследованием которых она занимается. В работе на примерах дается методологическое обоснование сравнительной интерпретации литературных произведений славянских авторов, которое базируется на тематических, поэтических, жанровых, стилевых и идейных явлениях, то есть на историко-литературных и культурологических фактах.

Ключевые слова: славянские литературы, поэтика культуры, интертекстуальная компаративистика, сравнительная методология, компаративная теория. 